\title{
Sequence Analyses of Three Immunoglobulin G Anti-virus Antibodies Reveal Their Utilization of Autoantibody-related Immunoglobulin Vh Genes, but Not V $\lambda$ Genes
}

\author{
De-Feng Huang, ${ }^{\star *}$ Tsaiwei Olee, ${ }^{*}$ Yasuhiko Masuho, ${ }^{5}$ Yoh-ichi Matsumoto, ${ }^{5}$ Dennis A. Carson, ${ }^{\star \|}$ and Pojen P. Chen ${ }^{\star \|}$ \\ * Departments of Medicine and Pathology, University of California, San Diego, La Jolla, California 92093-0663; "Department of \\ Molecular and Experimental Medicine, The Scripps Research Institute, La Jolla, California 92037; ${ }^{\ddagger}$ Department of Medicine, \\ Veterans General Hospital-Taipei, Taipei, Taiwan 11217; ${ }^{\S}$ Teijin Institute for Biomedical Research, Hino, Tokyo 191, Japan
}

\begin{abstract}
Accumulated sequence analyses of the antibody repertoire have revealed that most autoantibodies and developmentally regulated antibodies share a small set of germline Ig-variable region (V) genes. The findings have prompted speculation that certain autoantibodies are of developmental importance and may be instrumental in maintaining homeostasis of the adult antibody repertoire. In order to evaluate this hypothesis critically, it is first necessary to determine the $V$ gene usage in human antibodies against foreign substances. Unfortunately, only a few such antibodies have had their heavy and light chains characterized. To rectify the situation, we adapted the anchored polymerase chain reaction to clone and analyze rapidly the expressed $V$ genes for three anti-virus IgG antibodies. The results show that all three heavy chain $\mathrm{V}(\mathrm{Vh})$ genes are highly homologous to the known autoantibody-related $\mathrm{Vh}$ genes. In contrast, two light chain $\mathrm{V}$ (VL) genes of the $\mathrm{V} \lambda 1$ subgroup are similar to a non-autoantibody-related germline $V \lambda l$ gene. Taken together with the reported $V h$ and $V L$ sequences of several antibodies against viruses and bacteria, the data show that many antipathogen antibodies may use the same small set of $\mathrm{Vh}$ genes that encode autoantibodies, but diverse VL genes that are distinct from autoantibody-related VL genes. Thus, only a small portion of the potentially functional germline $\mathrm{Vh}$ genes are used recurrently to generate most antibodies in a normal antibody repertoire, regardless of their reactivities with either self or non-self. (J. Clin. Invest. 1992. 90:2197-2208.) Key words: anchored polymerase chain reaction $\bullet$ antibodies $\bullet$ herpes simplex virus • immunoglobulin $\mathrm{V}$ genes $\bullet$ varicella zoster virus
\end{abstract}

\section{Introduction}

A major characteristic of the humoral immune system is its ability to respond to the enormous number of different antigens routinely encountered in the environment. This is accom-

Dr. Masuho's current address is Yamanouchi Pharmaceutical Co., Ltd., 1-8, Azusawa 1-chome, Itabashiku, Tokyo 174, Japan.

Address reprint requests to Dr. Chen, Department of Medicine, 0663, University of California, San Diego, La Jolla, CA 92093.

Received for publication 22 January 1992 and in revised form 27 May 1992

J. Clin. Invest.

(C) The American Society for Clinical Investigation, Inc.

$0021-9738 / 92 / 12 / 2197 / 12 \$ 2.00$

Volume 90, December 1992, 2197-2208 plished by an antibody repertoire composed of $\sim 10^{7}$ to $10^{8}$ distinct antibody molecules. They differ from each other mainly in their variable (V) regions, ${ }^{1}$ which are responsible for the binding specificities of different antibody molecules. This enormous antibody diversity is generated by: $(a)$ independent assortments of numerous $\mathrm{V}$ genes, diversity (D) genes, and joining $(\mathrm{J})$ genes, coupled with imprecise joining and insertions of $\mathrm{N}$ region sequences; $(b)$ random pairing of heavy $(\mathrm{H})$ and light ( $\mathrm{L}$ ) chains; and $(c)$ somatic diversification, including mutations, gene conversions and gene replacements $(1,2)$. To date, accumulated data indicate that there are about $200 \mathrm{H}$ chain $\mathrm{V}(\mathrm{Vh})$ genes, $80 \kappa \mathrm{L}$ chain $\mathrm{V}\left(\mathrm{V}_{\kappa}\right)$ genes, and $100 \lambda \mathrm{L}$ chain $\mathrm{V}(\mathrm{V} \lambda)$ genes (3-7); among these $\mathrm{V}$ genes, about 30$50 \%$ are nonfunctional, owing to various defects in their coding regions, recombination and splicing signal sequences, and transcriptional regulatory regions.

During the last 5 years, intensive studies have revealed that many autoantibodies of different specificities recurrently use a small set of Ig V genes (8-12). For example, Humkv325 encodes the $\kappa \mathrm{L}$ chains of several rheumatoid factors (RFs), two antibodies against low-density lipoprotein, one antibody against intermediate filaments, and a few cold agglutinins ( 8 , 13 ); similarly, VH26 encodes the $\mathrm{H}$ chains of the $16 / 6$ idiotype-positive anti-DNA antibodies and an IgM antibody that binds to IgG, thyroglobulin, and other antigens (9, 10, 14-16). On the other hand, analysis of $\mathrm{Vh}$ gene expression during early ontogenic development showed that a small number of $\mathrm{Vh}$ genes were expressed frequently (17-19). For example, among 24 randomly chosen $\mathrm{Vh}$ clones characterized, 6 derived from the $56 \mathrm{pl}$ gene, 3 from the $20 \mathrm{pl}$ gene, and 2 each from five different Vh genes. Strikingly, most of these developmentally regulated $\mathrm{Vh}$ genes have been found to encode the $\mathrm{H}$ chains of autoantibodies $(8-10,12,19)$. Taken together with similar findings in mice, these data prompted postulation of a network hypothesis (20), which contends that, in the sterile fetal environment, only self-reactive B cells are stimulated and are thus selectively expanded to form the initial functional antibody repertoire.

Alternatively, the recurrent usage of a restricted set of $\mathrm{Vh}$ genes during early development may imply a broader immuno-

1. Abbreviations used in this paper: APCR, anchored polymerase chain reaction; $C D R$, complementarity-determining region; $C M V$, cytokegalovirus; FR, framework region; $\mathrm{H}$ chain, heavy chain; Hib, Haemophilus influenzae type b; HLA, human leukocyte antigen; HSV, herpes simplex virus; $\mathrm{L}$ chain, light chain; PCR, polymerase chain reaction; $\mathrm{RF}$, rheumatoid factor; $\mathrm{V}$, variable region; $\mathrm{Vh}, \mathrm{H}$ chain $\mathrm{V} ; \mathrm{V}_{\kappa}, \kappa \mathrm{L}$ chain $\mathrm{V}$; V $\lambda$, $\mathrm{L}$ chain $\mathrm{V}$; VZV, varicella-zoster virus. 
logical importance. In addition to coding for autoantibodies, a restricted $\mathrm{Vh}$ gene group might also encode the $\mathrm{H}$ chains of antibodies against common environmental pathogens, such as the herpesviruses. In support of this contention, it was shown previously that the EVI-15 anti-cytomegalovirus (CMV) antibody utilized the autoantibody-related Humhv1051 and Humkv325 genes, the $\mathrm{Vh}$ and the $\mathrm{V}_{\kappa}$ genes that encode many Wa-positive RFs $(8,21-23)$. To examine this hypothesis further, we adapted the anchored polymerase chain reaction (APCR) to clone and analyze rapidly the expressed $V$ genes for three IgG antibodies against herpes simplex virus (HSV) and varicella-zoster virus (VZV), both of the herpes family. We found that the $\mathrm{H}$ chains of all three antibodies apparently use Vh genes which had been shown to encode autoantibodies. In contrast, the L chains of two analyzed antibodies likely employ a $V \lambda 1$ gene that does not encode any autoantibody. Taken together with other findings (see Discussion), the current data indicate that certain Vh genes are utilized recurrently to encode both autoantibodies of developmental importance and antibodies against common environmental pathogens.

\section{Methods}

Characterization of hybridomas and their RNA isolation. The generation and characterization of all three hybridomas have been reported previously. Briefly, for $\mathrm{H} 2$ and $\mathrm{H} 3$, tonsil lymphocytes were obtained from patients with tonsillitis who were otherwise normal, stimulated in vitro with inactivated viral particles of the KOS strain of HSV-1 and pokeweed mitogen for $6 \mathrm{~d}$, and fused with mouse myeloma P3 $\times 63 \mathrm{Ag} 8 \mathrm{U} 1 \mathrm{cells}(24,25)$. Although the donors had anti-HSV antibodies in their sera, no anti-HSV hybridomas were obtained when the tonsil lymphocytes were either fused directly without preculture or cultured alone without HSV or pokeweed mitogen (24). For V1, spleen lymphocytes were obtained from one patient with idiotypic thrombocytopenic purpura, stimulated in vitro with the sonicated VZV-infected cells, and fused with $\mathrm{P} 3 \times 63 \mathrm{Ag} 8 \mathrm{U} 1$ (26). It should be noted that most hybridomas obtained from the in vitro stimulated lymphocytes secreted IgG1 antibodies (including $\mathrm{H} 2, \mathrm{H} 3$, and V1), suggesting that they came from a secondary immune response. Moreover, all three monoclonal anti-virus antibodies neutralized the respective viruses at a concentration of $1 \mu \mathrm{g} / \mathrm{ml}$; such activities are as potent as murine monoclonal antibodies derived from hyperimmunized mice. Together, the data indicate that these three anti-virus antibodies represent the high-affinity antibodies that are normally found in a secondary immune response. Their major characteristics are summarized in Table I. The mRNA was isolated from $10^{8}$ cells for each hybridoma with the Extract A Gene Kit (Oncor Inc., Gaithersburg, MD) according to the manufacturer's instructions.

Rapid cloning of the $\gamma H$ and $\lambda L$ chain $V$ region (Vh and $V \lambda$ ) cDNA by $\operatorname{APCR}(27,28)$. Recently, a synovium-derived RF was found to use a novel $V \lambda 8$ gene (29). To avoid any possible problems with unknown $\mathrm{V}$ gene families and to clone rapidly the expressed $\mathrm{V}$ genes in hybridomas, we adapted the reported APCR method (28). Briefly, for each V gene, the first strand cDNA was synthesized from $1 \mu \mathrm{g}$ of hybridoma mRNA with an oligo(dT) primer and Moloney murine leukemia virus reverse transcriptase; the cDNA was extracted once with phenol-chloroform, precipitated with $2.5 \mathrm{M}$ ammonium acetate, and resuspended in water. Then, a poly $(\mathrm{dG})$ tail was added to the $3^{\prime}$ end of the cDNA with terminal deoxynucleotidyl transferase. The tailed cDNA was amplified with two $5^{\prime}$ universal primers and a 3 ' primer for either the $\gamma \mathrm{H}$ chain or the $\lambda \mathrm{L}$ chain. The $5^{\prime}$ primers were the $\mathrm{AN}$ (for "anchor") primer (5'-CACGT-CGACC-TAGGC-GGCCG-CGG) and the ANpolyC primer ( 5 '-AN-CCCCC-CCCCC-CCCC, where AN stands for the AN primer sequence) (28); they were used at the 9:1 ratio. The 3 ' primers for the $\gamma$ chain and the $\lambda$ chain, respectively, were the GClc primer (where G, C, and c stand for the "gamma chain," "constant region," and the "complementary strand"; 5'-TGAGT-TCCAC-GACACCGT, complementary to a sequence marked in Fig. 1) and the LCc primer (where L stands for "lambda chain"; 5'-AGTGT-GGCCTTGTTG-GCTTG, complementary to nucleotides 410-391 in Figure 2 ). These two primers were designed to prime all $\gamma$ and $\lambda$ chains. Either a BamH1 or a Pst 1 site was added to the $5^{\prime}$ end of these two primers.

To the tailed cDNA and the appropriate primers, all four deoxynucleotide triphosphates and Taq polymerase were added, and the mixture was amplified for 30 cycles in a buffer containing $1.5 \mathrm{mM} \mathrm{Mg}$. Each cycle consisted of a 45 -s denaturation at $94^{\circ} \mathrm{C}$, a 45 -s primer annealing at $46^{\circ} \mathrm{C}$, and a 1 -min (except for a 7 -min in the last cycle) extension at $72^{\circ} \mathrm{C}$. The amplified products were visualized by running one tenth $(10 \mu \mathrm{l})$ of the reaction on a $1 \%$ agarose gel.

For each $\mathrm{Vh}$ gene and the $\mathrm{H} 3 \mathrm{~V} \lambda$ gene, to increase the quantity and quality of the desired $\gamma$ and $\lambda$ gene products, the amplified products of the expected size were enriched from the low melting gel and reamplified with the 5' AN primer and two new 3' primers, GCc and LClc (complementary to sequences marked in Figs. 1, 3, 4, and 5), respectively. Amplification was done in the same aforementioned conditions, except for annealing at $55^{\circ} \mathrm{C}$.

Cloning and sequencing of the amplified DNA. The amplified DNA was digested with the appropriate enzymes, and was cloned into M13mp8 (30). For the $\mathrm{H}$ and the $\mathrm{L}$ chain cDNAs, the recombinant

Table I. Immunological Properties of Three IgG Anti-virus Antibodies

\begin{tabular}{|c|c|c|c|}
\hline Name & $\mathrm{H} 2$ & H3 & v1 \\
\hline Isotype & $\gamma 1 \lambda 2$ & $\gamma 1 \lambda 3$ & $\gamma 1 \lambda 2$ \\
\hline Specificity & HSV-1,2 & HSV-1,2 & VZV \\
\hline Cross-reactivity & none & none & HSV-1,2 \\
\hline \multirow[t]{2}{*}{ No binding to } & uninfected cells* & uninfected cells & uninfected cells \\
\hline & $\mathrm{VZV}, \mathrm{CMV},{ }^{*} \mathrm{EBV}^{*}$ & VZV, CMV, EBV & CMV, EBV \\
\hline Antigen & $\mathrm{gB}^{\ddagger}$ & gB & gpII \\
\hline Neutralization & + & + & + \\
\hline Protection in mice & + & + & not tested \\
\hline
\end{tabular}

Balb/c mice was inoculated with a lethal dose of HSV-1 or -2 , with or without the testing antibodies. All infected mice without antibodies died within $15 \mathrm{~d}$ after inoculation. * All the viruses were propagated in human embryonic lung (HEL) cells; the uninfected cells represented uninfected HEL cells. ${ }^{\ddagger} \mathrm{gB}$ is a 120 -kD glycoprotein of HSV-1 and gpII represents 116-, 105-, and 64-kD glycoproteins of VZV. 
phages were screened with the GC3 (TCC-ACC-AAG-GGC-CCA-TC, positions 376-392 in Fig. 1) and the LC4 (TCG-GTC-ACT-CTGTTC-CCG, positions $355-372$ in Fig. 2) primers, respectively. The hybridization was done in $6 \times \operatorname{SSPE}(20 \times \mathrm{SSPE}$ is $3.6 \mathrm{M} \mathrm{NaCl}, 200 \mathrm{mM}$ sodium phosphate, $20 \mathrm{mM}$ EDTA, pH 7.4) containing $5 \times$ Denhart's solution ( $1 \times$ is $0.02 \%$ Ficoll, $0.02 \%$ polyvinylpyrrolidone, $0.02 \%$ bovine serum albumin ), at $50^{\circ} \mathrm{C}$. Hybridized filters were washed with $6 \times$ SSPE four times at room temperature for $15 \mathrm{~min}$ each and one time at $50^{\circ} \mathrm{C}$ for $1 \mathrm{~min}$; then, the positive clones were visualized by autoradiography. Single-stranded DNA was prepared from the chosen M13 clones, and the inserted DNA was sequenced by the method of Sanger using the universal M13 sequencing primer. Because of possible base infidelity generated during PCR amplification, each of the presented sequences represents either at least two completely identical sequences from the amplified DNA or a consensus sequence from at least three 99\% homologous sequences. The computer programs of the University of Wisconsin Genetics Computer Group were used to assemble, edit, and analyze all sequence data (31).

\section{Results}

Molecular characterization of the $\mathrm{H} 2 \mathrm{Vh}$ and $\mathrm{V \lambda} c \mathrm{DNA}$. The amplified DNA from APCR with GCc and LCc were analyzed by gel electrophoresis and were found to contain clean bands of expected sizes; the bands also hybridized respectively with the GC3 and the LC4 primers (located upstream of the GCc and the LCc primers). The results indicated that the bands contained the $\mathrm{Vh}$ and $\mathrm{V} \lambda$ cDNAs, respectively. Accordingly, the amplified DNA was cloned into M13 and the recombinants were analyzed. The results showed that the $\mathrm{H} 2$ antibody has a Vh3 gene and a V $\lambda 1$ gene, designated as Humha $3 \mathrm{~h} 2$ and Humla 1h2, respectively (Figs. 1 and 2).

A comparison of the $\mathrm{V}$ gene-encoded regions in ha3h 2 and la $1 \mathrm{~h} 2$ with both Genbank and EMBL databases revealed that the expressed $\mathrm{Vh}$ and $\mathrm{V} \lambda$ genes were most homologous to VH26 and IGLV1S2 (abbreviated lv1s2) (15, 32-34), respec-

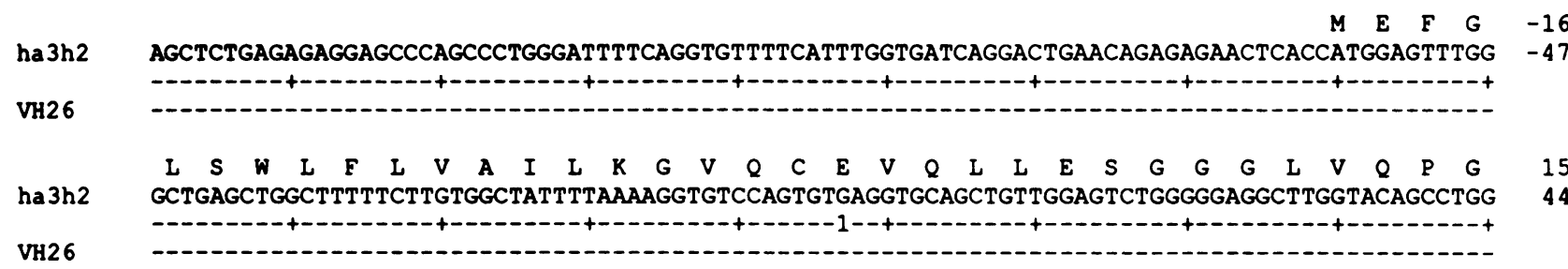
GGGGTCCCTGAGACTCTCCTGTGCAGCCTCTGGGTTCACCTTTAGCGGCTATGCCATGAGCTGGGTCCGCCAGGCTCCAGGGAAGGGGCT 134

Figure 1. The nucleotide and amino acid sequences of the $\mathrm{H} 2 \mathrm{H}$ chain $\mathrm{V}$ region, designated $\mathrm{Humha} 3 \mathrm{~h} 2$, and abbreviated ha3h2 (accession no. M97920). The nucleotide sequence in the Vh gene-encoded region was compared with all Vh gene sequences in the GenBank and EMBO databases, and the most homologous VH26 gene is given for comparison $(32,33)$. The expressed V gene was rearranged to a Jh6 and a $\gamma 1$ genes $(11,37)$; their reported germline sequences are included for comparison. The nucleotide sequence in the CDR 3 of ha3h2 was compared with all reported Dh gene sequences, and the most homologous Dk1 Dh gene segment is given for comparison (36). The complete nucleotide and amino acid sequences of ha3h2 are given, while all other sequences are given only at the positions where they differ from ha3h2, in the overlapping regions. The bars denote the identities. The regions of two oligomers are underlined and their names are given underneath. The CDRs are marked. 
tively; the latter two germline gene sequences are included in Figs. 1 and 2 for comparison. Significantly, ha3h 2 is identical to VH26 in the 5' flanking region of $79 \mathrm{bp}$ and the leader region of $57 \mathrm{bp}$. It is known that among different gene members of a Vh gene family, their flanking regions are normally more heterogeneous than their coding region counterparts; as such, the 5 ' flanking region of an expressed $\mathrm{Vh}$ gene generally provides the best clue about its germline origin. In this context, the aforementioned data suggested very strongly that ha3h2 was encoded by VH26.

Therefore, the 13 nucleotides by which ha3h 2 differs from VH26 represent somatic mutations; they consisted of one double-base change and 11 single-base changes (Fig. 1). Of the 13 mutations, 8 were in the complementarity-determining regions (CDRs) and 5 in the framework regions (FRs). Interestingly, seven of eight $(88 \%)$ changes in CDRs were replacement changes, while only three of five $(60 \%)$ changes in the FR were replacement changes; thus, the ratio of replacement over silent changes ( $R / S)$ is 7 in CDRs and 1.5 in FRs, respectively. Generally, an $R / S$ ratio of $>2.9$ suggests an antigen-driven response (35). Accordingly, an R/S ratio of 7 in the CDRs of $\mathrm{H} 2$ is consistent with its generation from HSV-immunized $B$ cells (25).

On the other hand, although la $1 \mathrm{~h} 2$ differs from lv1s 2 by two nucleotides in their 5 ' flanking regions, the deviated $\mathrm{C}$ and $\mathrm{G}$ in lalh2 were shared by lalvl (to be described later in Fig. $6)$, suggesting that these two different bases are likely to repre- sent allelic differences, or alternatively a highly related but different $\mathrm{V} \lambda \mathrm{l}$ gene. Nevertheless, among the five base differences between la1h2 and lv1s2, two are in CDRs and three are in FRs. Interestingly, both different bases in CDRs cause amino acid changes, while only one of three in FRs leads to amino acid change.

The CDR 3 of ha3h 2 contained a stretch of a 7-bp segment which was identical to the Dk1 gene (36) (Fig. 1). Also, the ha3h2 $\mathrm{H}$ chain employed a Jh6 and a $\mathrm{C} \gamma 1$ gene (Fig. 1); its Jh region deviated from a Jh6 sequence by three replacement changes ( 11 ), while its $\mathrm{C} \gamma 1$ region was identical to the reported $\mathrm{C} \gamma 1$ sequence over a 77-bp region (37). On the other hand, the la $1 \mathrm{~h} 2 \mathrm{~L}$ chain utilized a $\mathrm{J} \lambda 2$ and $\mathrm{C} \lambda 2$ gene $(38,39)$, instead of the closely related $C \lambda 3$ gene, based on a single diagnostic base ( $G$ vs. A) at nucleotide position 372 (Fig. 2). The expressed $\mathrm{J} \lambda 2$ sequence deviated from the reported germline sequence by one replacement change, while its $C \lambda 2$ sequence was identical to the known $\mathrm{C} \lambda 2$ gene over a 56-bp region.

Molecular characterization of the $H 3 \mathrm{Vh}$ and $V \lambda c D N A$. When $1 \mu \mathrm{g}$ of mRNA from the H3 IgG anti-HSV hybridoma was amplified and analyzed, it was found that the $\mathrm{H} 3$ antibody has a Vh4 and a V $\lambda 3$ gene, designated Humha4h3 and Humla3h3, respectively (Figs. 3 and 4). Sequence comparisons of the $\mathrm{V}$ gene-encoded regions in ha4h3 and la $3 \mathrm{~h} 3$ with both Genbank and EMBL databases revealed that the expressed $\mathrm{Vh}$ and $\mathrm{V} \lambda$ genes were most homologous to $\mathrm{Vh} 4.18$ and cML70, respectively; Vh4.18 is a germline gene, while

$\begin{array}{llllllllllllll}M & A & \text { W } & S & P & \text { L } & \text { L } & \text { L } & \text { T } & \text { L } & \text { L } & \text { A } & \text { H } & -7\end{array}$

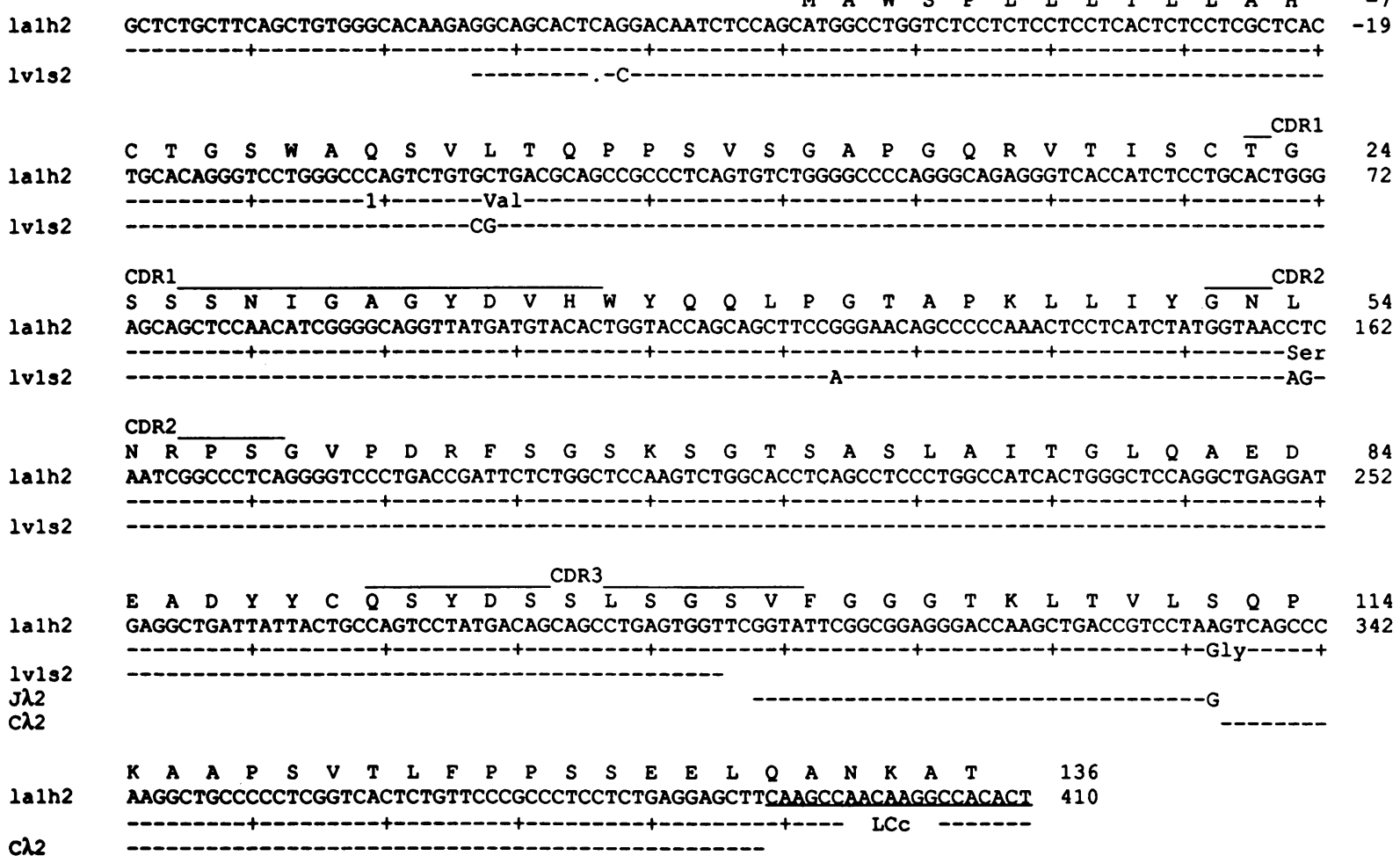

Figure 2. The nucleotide and amino acid sequences of the H2 L chain V region, designated Humlalh2, and abbreviated la1h2 (accession no. M97922). The nucleotide sequence of the most homologous iglv1s2 gene is given for comparison. The expressed $\mathrm{V}$ gene was rearranged to a $\mathrm{J} \lambda 2$ and $\mathrm{C} \lambda 2$ gene $(38,39)$; their reported germline sequences are included for comparison. The complete nucleotide and amino acid sequences of lalh2 are given, while all other sequences are given only at the positions where they differ from lalh2, in the overlapping regions. The bars denote the identities; the region of the LCc oligomer is marked. The CDRs are marked. 
v2-1

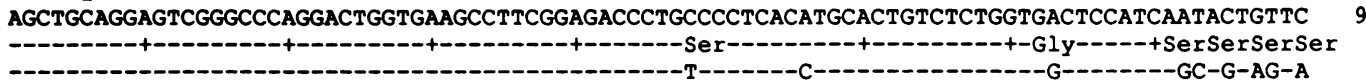

2-1

CDR1

$Y \bar{Y}$ W G W I R O A P G K G I E W I G S I Y Y

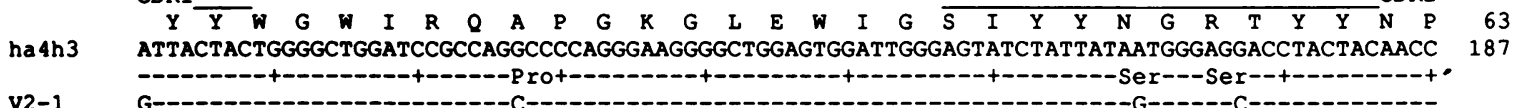

v2-1 G-1

CDR2

$\begin{array}{lllllllllllllllllllllllllllllllll}S & \text { I } & K & S & R & V & T & V & S & V & D & T & S & T & N & Q & F & S & L & R & L & R & S & V & T & A & A & D & T & A & 93\end{array}$

ha 4 h3 CGTCCCTGAAGAGCCGAGTCACAGTATCCGTGGACACGTCCACGAATCAGTTCTCCCTGAGGCTGAGGTCTGTGACCGCCGCAGACACGG 277

V2-1 -1 -

CDR3

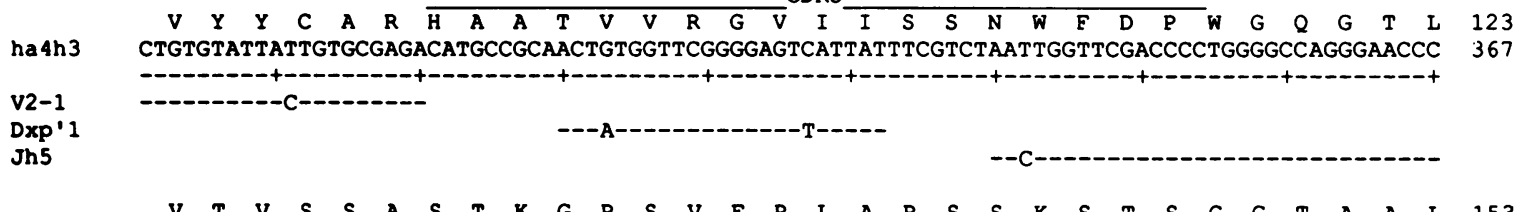

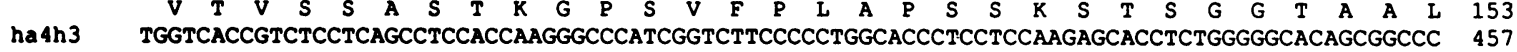

Jh5

r

$\cosh 3$

$\begin{array}{lllllllllllllllllll}G & C & L & V & K & D & Y & F & P & E & P & V & T & V & S & \boldsymbol{W} & N & S & 171\end{array}$

ha4h3 TGGGCTECCTGGTCAAGGACTACTTCCCCGAACCGGTGACGGTGTCGTGGAACTCA 513

$\boldsymbol{\gamma}$

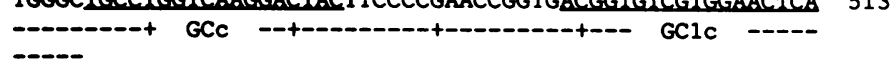

Figure 3. The nucleotide and amino acid sequences of the $\mathrm{H} 3 \mathrm{H}$ chain $\mathrm{V}$ region, designated Humha4h3, and abbreviated ha4h3 (accession no. M97921). The nucleotide sequence in the Vh gene-encoded region was compared with all Vh gene sequences in the GenBank and EMBO databases, and the most homologous V2-1 gene is given for comparison (41). The expressed V gene was rearranged to a Jh5 and a $\gamma 1$ genes ( 11,37 ); their reported germline sequences are included for comparison. The nucleotide sequence in the CDR 3 of ha4h 3 was compared with all reported $\mathrm{Dh}$ gene sequences, and the most homologous Dxp'l Dh gene segment is given for comparison (36). The complete nucleotide and amino acid sequences of ha $4 \mathrm{~h} 3$ are given, while all other sequences are given only at the positions where they differ from ha4h 3 , in the overlapping regions. The bars denote the identities. The regions of two oligomers are underlined and their names are given underneath. The CDRs are marked.

cML70 is a cDNA cloned from the spleen of an 86 year accident victim $(7,40)$. The reported Vh4.18 gene was cloned by PCR and contains only the Vh gene-encoded region, but not its 5 ' flanking, leader, intron and leader' regions; however, Vh4.18 differs from the V2-1 germline Vh4 gene by only 1 replacement change, and the 5 ' flanking and leader-intron-leader' regions of V2-1 had been characterized (41). Thus, V2-1 is given in Fig. 3 for comparison. The cML 70 is also given in Fig. 4 for comparison.

As can be seen in Fig. 3, ha4h3 differs from V2-1 by four bases in the $5^{\prime}$ flanking region, suggesting that ha $4 \mathrm{~h} 3$ may be encoded by a yet unidentified Vh4 germline gene. Nevertheless, among the 24 nucleotides by which ha4h 3 differs from V2-1 in the secreted V region, 9 are in CDRs, including 7 replacement changes, resulting an $R / S$ ratio of 3.5 ; of the 15 differences in FRs, 9 are replacement changes, resulting an $R /$ $S$ ratio of 1.5 .

The CDR 3 of ha $4 \mathrm{~h} 3$ contains a 23 bp segment which is very similar to the Dxp'l gene (36), suggesting that the ha4h3 heavy chain apparently uses this Dh gene (Fig. 3). Also, the ha4h3 H chain employs Jh5 and $\mathrm{C} \gamma 1$ genes (Fig. 1); its Jh region deviated from a Jh5 sequence by one silent change (11), while its $\mathrm{C}_{\gamma} 1$ region was identical to the reported $\mathrm{C} \gamma 1$ sequence over a 77-bp region (37). On the other hand, the la3h3 $\mathrm{L}$ chain utilized a $\mathrm{J} \lambda 3$ and $C \lambda 3$ gene $(38,39)$, instead of the closely related $\mathrm{C} \lambda 2$ gene, based on a single diagnostic base ( $A$ vs. $G$ ) at nucleotide position 363 (Fig. 4). The expressed $J \lambda 3$ sequence deviated from the reported germline sequence by two replacement changes and two silent changes, while its $C \lambda 3$ sequence was identical to the known $\mathrm{C} \lambda 3$ gene over a 39-bp region.

Molecular characterization of the VI Vh and $V \lambda c D N A$. In addition to two IgG anti-HSV antibodies, we also analyzed one IgG anti-VZV antibody, termed V1. The results showed that the $\mathrm{V} 1$ antibody has a Vh1 and $\mathrm{V} \lambda 1$ genes, designated as Humhalv1 and Humlalv1, respectively (Figs. 5 and 6). A computer sequence analyses revealed that halv1 was most closely related to the VH1GRR germline gene, and that la 1v1 was most homologous to lv1s2 $(42,43)$; the latter two germline gene sequences are included in Figs. 5 and 6 for comparison. Significantly, halv1 is identical to VH1GRR in the signal peptide region (of $27 \mathrm{bp}$ ). Thus it is very likely that halv1 is encoded by VHIGRR. Among the difference of 22 nucleotides between halv1 and VHIGRR, 12 are in CDRs, including 10 replacement changes and resulting an $\mathrm{R} / \mathrm{S}$ ratio of 5 ; of the remaining 10 in FRs, 2 are replacement changes, resulting in an $\mathrm{R} / \mathrm{S}$ ratio of 0.25 . 


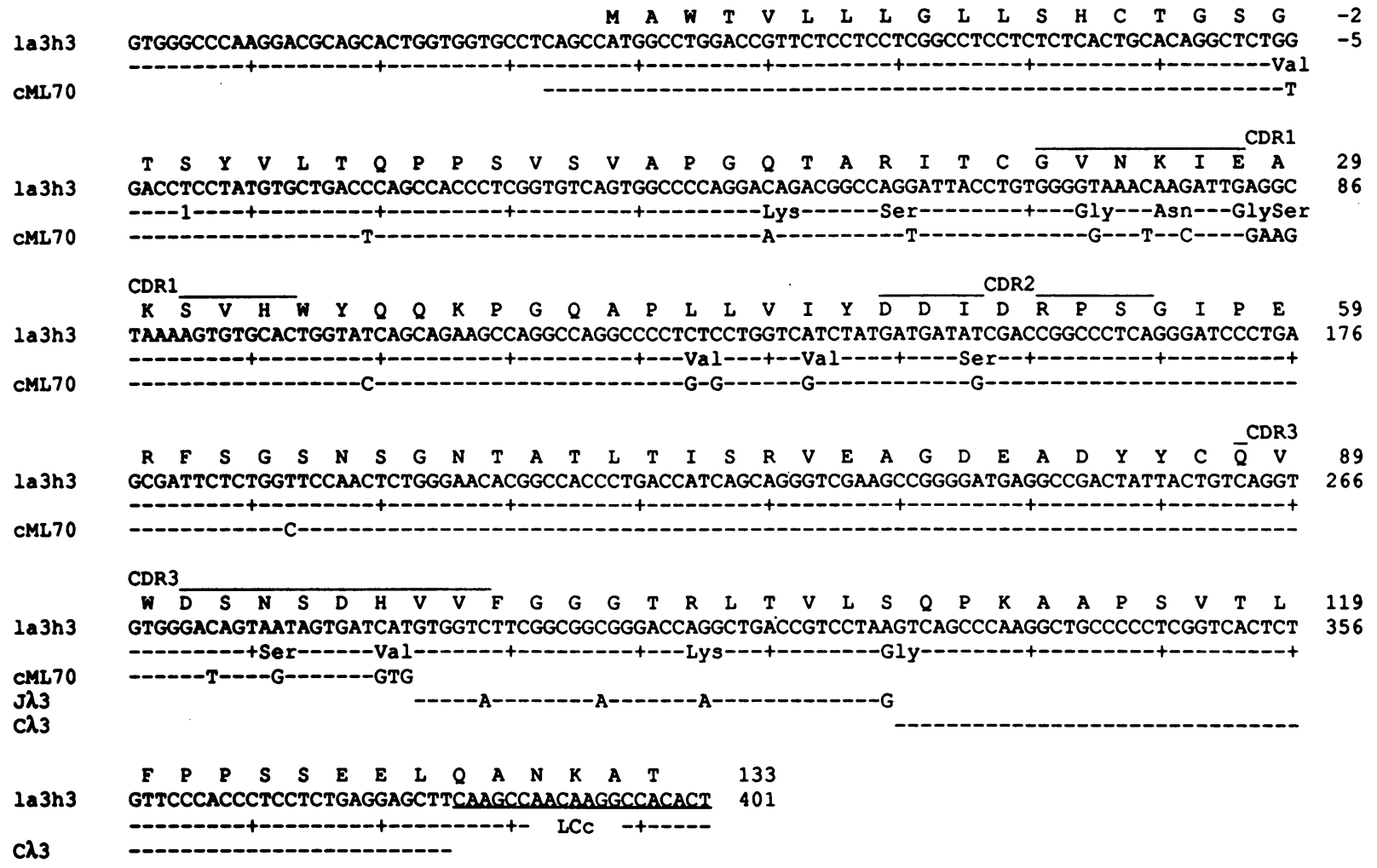

Figure 4. The nucleotide and amino acid sequences of the $\mathrm{H} 3 \mathrm{~L}$ chain $\mathrm{V}$ region, designated Humla $3 \mathrm{~h} 3$ and abbreviated la $3 \mathrm{~h} 3$ (accession no. M97924). Because of limited information about $V \lambda 3$ genes, the nucleotide sequence of the most homologous cML70 cDNA is given for comparison (7). The expressed $V$ gene was rearranged to a $J \lambda 3$ and $C \lambda 3$ gene $(38,39)$; their reported germline sequences are included for comparison. The complete nucleotide and amino acid sequences of la $3 \mathrm{~h} 3$ are given, while all other sequences are given only at the positions where they differ from la3h3, in the overlapping regions. The bars denote the identities; the regions of two oligomers are marked and their names are given at below. The CDRs are marked. Primer LClc is complementary to nucleotides 409-426.

On the other hand, the one base difference between la1v1 and lv1s2 in their leader region suggests that lalv1 might be encoded by a yet unidentified $\mathrm{V} \lambda 1$ gene. Nevertheless, among the 17 base differences, 11 are in CDRs and 6 are in FRs. Interestingly, 9 of 11 differences in CDRs lead to amino acid changes, resulting in an $R / S$ ratio of 4.5 ; in contrast, only 3 of 6 differences in FRs are replacement changes, resulting in an $\mathrm{R} / \mathrm{S}$ ratio of 1 .

The CDR3 of halv1 contained two nonoverlapping stretches which were respectively similar to the $\mathrm{Dn} 4$ and the D2 genes in their reverse orientations (Fig. 5) (36). Also, the halv1 $\mathrm{H}$ chain employed $\mathrm{Jh} 3$ and $\mathrm{C} \gamma 1$ genes (Fig. 5); its $\mathrm{Jh}$ region deviated from a $\mathrm{Jh} 3$ sequence by 1 replacement change (11), while its $\mathrm{C}_{\gamma} 1$ region was identical to the reported $\mathrm{C}_{\gamma} 1$ sequence over a 77-bp region (37). On the other hand, the la $1 v 1 L$ chain utilized a $J \lambda 2$ and $C \lambda 2$ gene $(38,39)$, instead of the closely related $C \lambda 3$ gene, based on a single diagnostic base ( $\mathrm{G}$ vs. A) at nucleotide position 375 (Fig. 6). The expressed $\mathrm{J} \lambda 2$ sequence deviated from the reported germline sequence by one replacement change, while its $C \lambda 2$ sequence was identical to the known $\mathrm{C} \lambda 2$ gene over a 56-bp region.

\section{Discussion}

In an effort to assess the Ig $\mathrm{V}$ gene usage by the immunologically important antibody molecules in normal individuals, we cloned and sequenced the expressed Ig V genes of three IgG antibodies which are specific for common environmental pathogens, namely HSV and VZV. The results are summarized in Table II; they show that $(a)$ the $\mathrm{H} 2$ anti-HSV antibody uses the ha3h2 Vh3 gene and the la $1 \mathrm{~h} 2 \mathrm{~V} \lambda 1$ gene; (b) the $\mathrm{H} 3$ anti-HSV antibody uses the ha $4 \mathrm{~h} 3 \mathrm{Vh} 4$ gene and the la $3 \mathrm{~h} 3 \mathrm{~V} \lambda 3$ gene; and (c) the V1 anti-VZV antibody uses the ha1v1 Vh1 gene and the la $1 \mathrm{v} 1 \mathrm{~V} \lambda 1$ gene. The $\mathrm{H}$ chains of all three antibodies are of the IgG1 subclass; the $\mathrm{L}$ chains of $\mathrm{H} 2$ and $V 1$ are $C \lambda 2$, while the $\mathrm{H} 3 \mathrm{~L}$ chain is $\mathrm{C} \lambda 3$.

Although the three expressed Vh genes come from three different Vh gene families, it is a bit surprising to note that, by nucleotide sequence comparison, each expressed $\mathrm{Vh}$ gene is very likely to be encoded by (or is most similar to) a germline Vh gene that has been shown previously to code for certain autoantibodies (Table III). This provocative finding immediately prompted us to review all the reported DNA sequences of human antibodies that are specific for any infectious agents, to identify their putative germline origins, and subsequently to determine their usage by autoantibodies and their expression during ontogenic development. As can be seen in Table 3 (3, 4, $9,14-16,18,19,21,32,40,41,43-56)$, it is astonishing to find that, without a single exception, the $\mathrm{H}$ chain of each anti-pathogen antibody apparently derived from a Vh gene that is known to encode one or a few autoantibodies. In addition, it is noteworthy that, of nine antipathogen Vh genes, five have been found in the early antibody repertoire. 


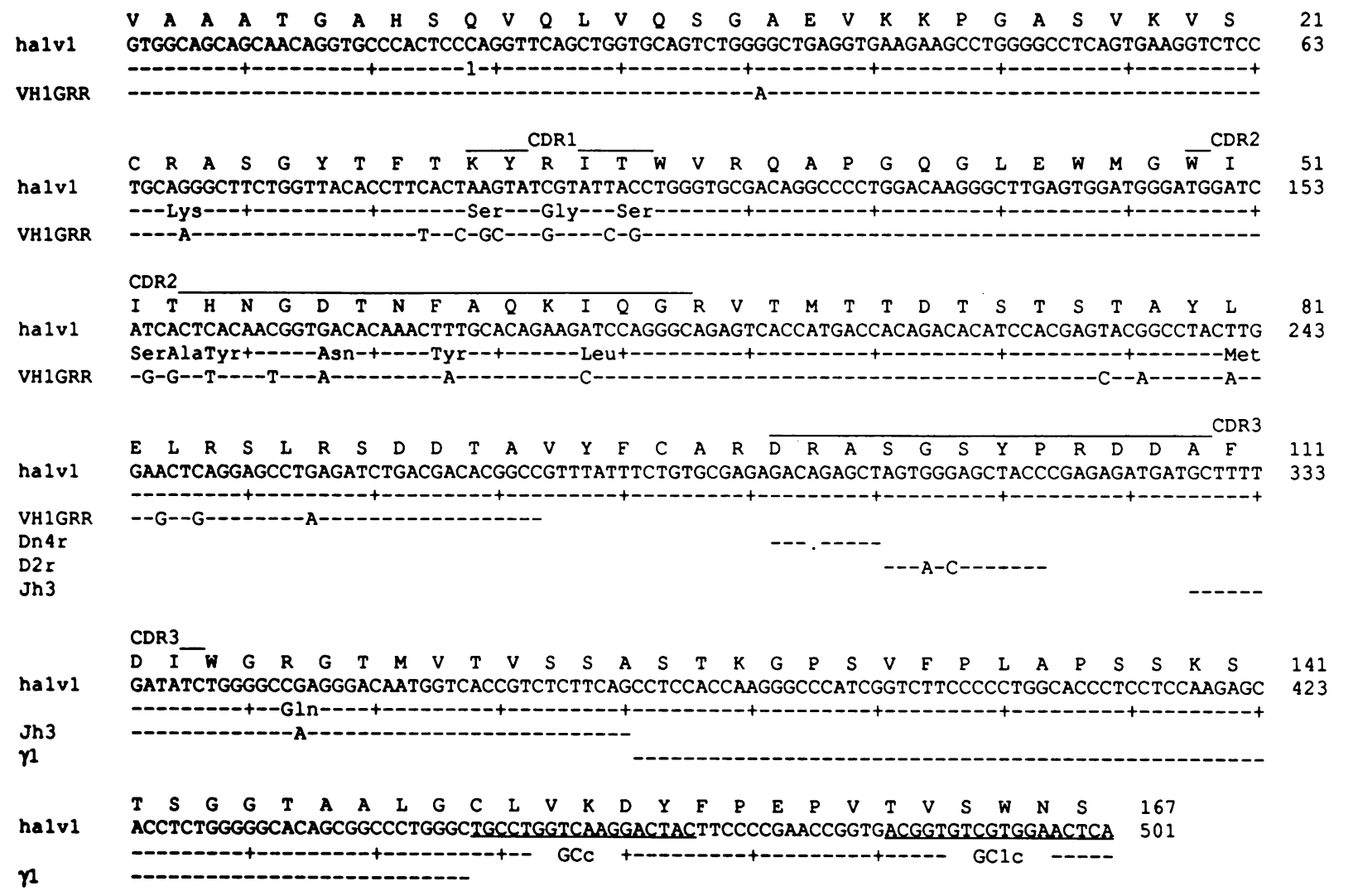

Figure 5. The nucleotide and amino acid sequences of the V1 H chain V region, designated Humbalv1, and abbreviated halvl (accession no. M97919). The nucleotide sequence in the Vh gene-encoded region was compared with all reported Vh gene sequences, and the most homologous VH1GRR gene is given for comparison (43). The expressed V gene was rearranged to a Jh3 and a $\gamma 1$ genes (11, 37); their reported germline sequences are included for comparison. The nucleotide sequence in the CDR3 of halvl was compared with all reported Dh gene sequences, and the most homologous Dn4r and D2r Dh gene segments ( the " $r$ " denotes the reverse orientation) are given for comparison (36). The complete nucleotide and amino acid sequences of halvl are given, while all other sequences are given only at the positions where they differ from halv1, in the overlapping regions. The bars denote the identities. The regions of two oligomers are underlined and their names are given underneath. The CDRs are marked.

Similar to the Vh genes, the expressed $V \lambda$ genes of the three currently analyzed anti-virus antibodies also come from different $V \lambda$ gene families; la $1 \mathrm{~h} 2$ and la1v1 are from the $V \lambda 1$ gene family, while la $3 \mathrm{~h} 3$ is from the $V \lambda 3$ gene family. Because of limited information about germline human $V \lambda 3$ genes, we have included only one other expressed $V \lambda 3$ gene (cML70) that was most closely related to la $3 \mathrm{~h} 3$ in Fig. 4 . On the other hand, there are four reported germline $V \lambda 1$ genes, i.e., Humlv117, V $\lambda 1.1$, iglv1s2, and Humlv1L1; all are functional $(34,42,57,58)$. Among them, lv117 is identical to the $\mathrm{L}$ chain of the Kim4.6 anti-DNA antibody and $1 \mathrm{v} 1 \mathrm{~L} 1$ encodes the $\mathrm{L}$ chain of the L1 IgG RF (Table IV). Moreover, by amino acid sequence comparison, each of these two genes is highly homologous to $\sim 40-50 \%$ of $\mathrm{V} \lambda 1 \mathrm{~L}$ chains that have been sequenced, suggesting that each of them apparently encode many other autoantibodies (57). In contrast, iglv $1 \mathrm{~s} 2$ has not been found to encode any autoantibody, and is unlikely to encode any one of the 16 characterized $V \lambda 1 \mathrm{~L}$ chains. Taken together, the $\mathrm{H} 2$ anti-HSV and the V1 anti-VZV antibodies most likely employ a $\mathrm{V} \lambda 1$ gene that is not related to any autoantibody. Among the additional $\mathrm{L}$ chains of anti-pathogen antibodies in Table III, only the EVI-15 L chain has been analyzed; it apparently derives from Humkv 325 , a $V_{k} 3$ gene that encodes most, if not all, Wa-idiotype positive IgM RF paraproteins, as well as several monospecific IgM RFs from patients with rheumatoid arthritis $(13,21,23,59,60)$. Very recently, during the course of revising this communication, the $\mathrm{L}$ chains of several antibacteria antibodies in Table III were characterized and reported (61). The results show that they derive from several different gene families: $a V_{\kappa} 1$ and $a V_{\kappa} 2$ genes, as well as a $V \lambda 2$ and a $\mathrm{V} \lambda 7$ genes (Table IV). Of the four, the $\mathrm{O} 12 \mathrm{~V}_{\kappa} 1$ gene apparently encodes the $15 \mathrm{~A}$ anti-I cold agglutinin $(62,63)$. To counter the possibility that the difference between the $V$ gene utilization patterns of $\mathrm{H}$ and $\mathrm{L}$ chains in anti-pathogen antibodies is due to limited information on VL gene usage, Table IV includes the reported $\mathrm{L}$ chain $\mathrm{V}$ gene usage of the autoantibodies listed in Table III. Both LS2 and Kim13.1 are encoded by the $\mathrm{Vg} \mathrm{V} \kappa 3$ gene, which is not known to encode any antipathogen antibodies. Also, Table IV contains a RF that uses a $\mathrm{V}_{\kappa} 2 \mathrm{~L}$ chain. Viewed as a whole, the current data show that there is no extensive overlap between the $L$ chains of autoantibodies and anti-pathogen antibodies.

What is the meaning of the extensive overlap between the $\mathrm{Vh}$ genes used for anti-pathogen antibodies and the $\mathrm{Vh}$ genes used for autoantibodies in Table III? Considering that many germline human Vh genes remain to be identified and characterized, and that several analyzed human $\mathrm{Vh}$ genes are known to be polymorphic, the sequence differences between each ex- 


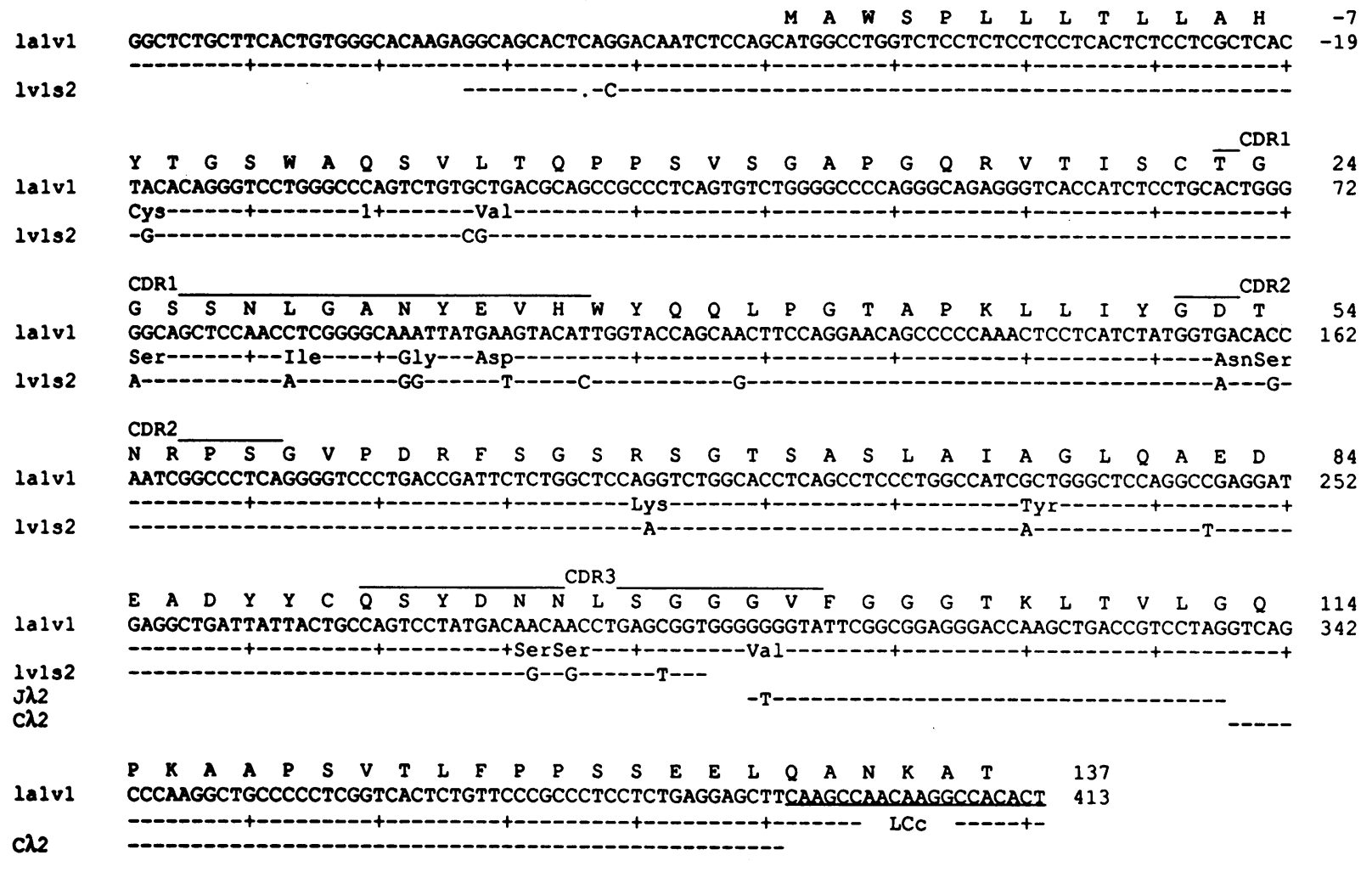

Figure 6. The nucleotide and amino acid sequences of the V1 L chain V region, designated Humlalv1 and abbreviated lalv1 (accession no. M97923). The nucleotide sequence of the most homologous iglv1s2 gene is given for comparison (34). The expressed $\mathrm{V}$ gene was rearranged to a $\mathrm{J} \lambda 2$ and $\mathrm{C} \lambda 2$ gene $(38,39)$; their reported germline sequences are included for comparison. The complete nucleotide and amino acid sequences of lalvl are given, while all other sequences are given only at the positions where they differ from lalvl in the overlapping regions. The bars denote the identities; the region of the LCc oligomer is marked. The CDRs are marked.

pressed Vh sequence and its putative germline Vh gene may indicate that the true germline counterpart of that expressed Vh sequence is yet to be identified. Thus, the tentative germline gene assignments for some of the anti-pathogen antibodies in Table III may be incorrect. However, it is very unlikely that all or the majority of putative Vh genes given in Table III are not the correct germline counterparts of the analyzed antibodies. Furthermore, a similar sequence comparison of $\mathrm{L}$ chains in Table IV does not reveal extensive overlap between antipathogen antibodies and autoantibodies. It is also extremely unlikely that the restricted Vh gene usage merely reflects an artefact of the hybridoma technology, because the cells compiled in Table III were generated by various techniques in several different laboratories. For example, except for M030, all the anti-HIV antibodies were generated by initial EBV transformation and subsequent fusion with the SHM-D33 heterohybridoma cell; anti-Haemophilus influenzae type $\mathrm{b}$ (Hib) antibodies were produced by direct fusion of PBL with the murine SP2/OAg14 cell; similarly, $18 / 2$ was derived from direct fusion of PBL with the human GM4672 cell; and C6B2 and 2A4 were generated by EBV transformation only. Thus, considering all available data in totality, the observed overlaps between the $\mathrm{H}$ chains of anti-pathogen antibodies and those of autoantibodies are likely to reflect a real bias in the expressed normal $\mathrm{Vh}$ gene repertoire that utilizes only a selected portion of the total potentially functional set of $\mathrm{Vh}$ genes. Importantly, during the

Table II. Ig Gene Usage of Three IgG Anti-virus Antibodies

\begin{tabular}{|c|c|c|c|c|c|c|c|}
\hline Name & Vh & D & Jh & C & $v \lambda$ & $\mathbf{J} \lambda$ & $\mathrm{C} \lambda$ \\
\hline $\mathrm{H} 2$ & VH26 Vh3 & Dk1 & 6 & $\gamma 1$ & $1 \mathrm{v} 1 \mathrm{~s} 2 \mathrm{~V} \lambda 1$ & 2 & 2 \\
\hline H3 & V2-1 Vh4 & Dxp'1 & 5 & $\gamma 1$ & cML70 V $\lambda 3$ & 3 & 3 \\
\hline V1 & VHIGRR VhI & $\mathrm{Dn} 4 \mathrm{r}, \mathrm{D} 2 \mathrm{r}$ & 3 & $\gamma 1$ & $1 \mathrm{v} 1 \mathrm{~s} 2 \mathrm{~V} \lambda 1$ & 2 & 2 \\
\hline
\end{tabular}

Except for the cML70 cDNA, all V and D gene segments are the germline genes that are most homologous to the respective rearranged genes; the $\mathrm{J}$ and $\mathrm{C}$ genes are the accurate assignment for the respective rearranged genes. 
Table III. Shared Ig Vh Gene Usage between Anti-pathogen Antibodies and Autoantibodies

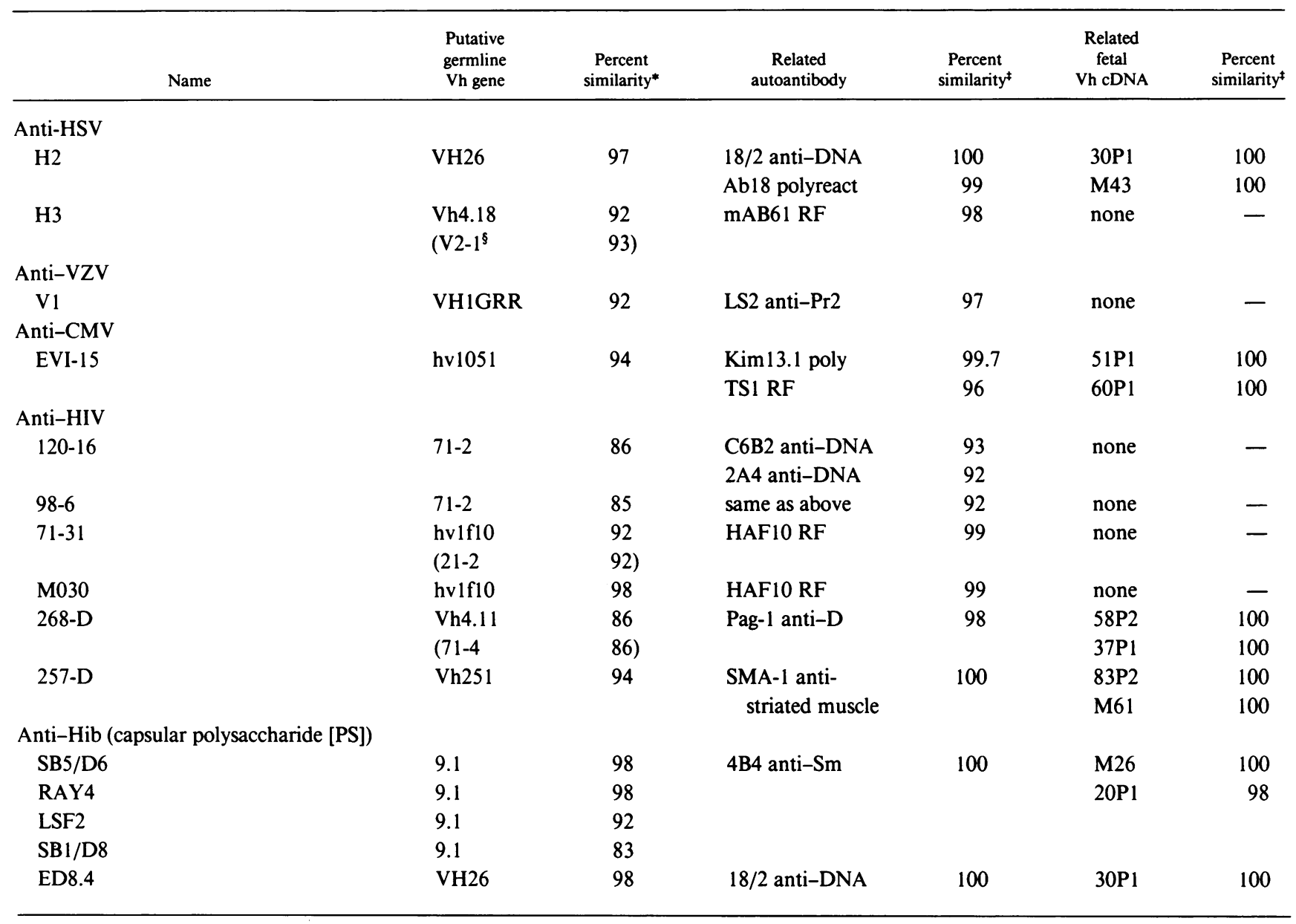

The data of $\mathrm{H} 2, \mathrm{H} 3$, and $\mathrm{V} 1$ are from the current communication; hv1051 is a germline Vh1 gene cloned recently in our laboratory and is identical to 51P1 in the Vh gene-encoded region (unpublished data); all the other data are from the literature: EVI-15 (21); except for M030 (44), all anti-HIV antibodies (45); anti-Hib antibodies (46); VH26 (15, 32); Vh4.18 and 4.11 (40); V2-1, 71-2, and 71-4 (3, 41): VH1GRR (43); hv1f10 and HAF10 RF (47); $21-2$ and 9.1 (4); Vh251 (40, 48); 18/2 (14); Ab18 polyreactive autoantibody (16); mAB61 (49); LS2 cold agglutinin (50); Kim 13.1 polyreactive autoantibody (51); TS1 (52); C6B2 (53); 2A4 (54); Pag-1, specific for the D antigen of the Rh-blood group (55); SMA-1 (11); 4B4 (56); all fetal antibodies $(17,18) .^{*}$ The percent similarity after each germline gene denotes its DNA sequence similarity to the Vh gene-encoded region in the preceding antibody. ${ }^{\ddagger}$ The percent similarity after each expressed $\mathrm{Vh}$ sequence denotes its DNA sequence similarity to the preceding germline $\mathrm{Vh}$ gene on the same section. ${ }^{\S}$ The germline $\mathrm{Vh}$ gene in parentheses is $>99 \%$ homologous to the preceding germline $\mathrm{Vh}$ gene in the same section; the two genes may represent either allelic forms of an identical Vh gene or different $\mathrm{Vh}$ genes residing in different loci of a haploid genome.

revision of this paper, a similar conclusion was reported by Braun et al. (64) using an entirely different approach.

A central dogma of the "clonal selection theory" is that only B cells that can interact meaningfully with antigens are stimulated to proliferate. In this context, the current observation may suggest that, in the sterile environment of a normal healthy individual, certain germline $\mathrm{Vh}$ genes when expressed on the surface of pre-B cells may interact with self antigens, and thus are expanded to form the "preinfection" (or "natural") antibody repertoire. Consequently, when the host encounters any environmental pathogen, the preferentially expressed $\mathrm{Vh}$ genes will be the first set of $\mathrm{Vh}$ genes to interact with the invading pathogens and to be selected by such pathogens. In essence, similar to the positive selection of the $T$ cell $\mathrm{V} \beta$ genes that interact with human leukocyte antigens (HLA), the self-reactive B cell Vh genes may also be selected positively; at the same time, the Vh genes that react too strongly with the self antigens are deleted, analogous to the negative selection for certain $\mathrm{T}$ cell $\mathrm{V} \beta$ genes that bind with high affinity to self antigens (65). Furthermore, the findings of common V gene usage in $\mathrm{H}$ chains, but not $\mathrm{L}$ chains, of anti-pathogen and self-reacting antibodies may suggest that the positive selection is initiated at the pre- $B$ cell stage, when the rearranged $H$ chains are co-expressed with surrogate $L$ chains (i.e., $\lambda 5$ and Vpre-B) (66).

In addition, the current data may suggest that the potentially functional $\mathrm{Vh}$ gene repertoire is significantly smaller than the structural Vh gene repertoire. This would imply that many supposedly functional Vh genes are indeed nonfunctional, perhaps owing to subtle defects in recombination signal se- 
Table IV. Most Anti-pathogen Antibodies and Autoantibodies Apparently Use Different Light Chain Ig V Genes

\begin{tabular}{|c|c|c|c|c|}
\hline Anti-pathogen antibodies & $\begin{array}{l}\text { Putative } \\
\text { germline gene }\end{array}$ & $\begin{array}{c}\text { Percent } \\
\text { similarity* }\end{array}$ & $\begin{array}{c}\text { Related } \\
\text { autoantibody }\end{array}$ & $\begin{array}{c}\text { Percent } \\
\text { similarity }{ }^{\ddagger}\end{array}$ \\
\hline \multicolumn{5}{|l|}{ Anti-HSV } \\
\hline $\mathrm{H} 2$ & $1 \mathrm{v} 1 \mathrm{~s} 2 \mathrm{~V} \lambda 1$ & 97 & none & - \\
\hline H3 & $\mathrm{cML70} \mathrm{V} \lambda 3$ & 90 & none & - \\
\hline Anti-VZV & & & & \\
\hline V1 & $1 \mathrm{v} 1 \mathrm{~s} 2 \mathrm{~V} \lambda 1$ & 91 & none & - \\
\hline \multicolumn{5}{|l|}{ Anti-CMV } \\
\hline \multirow[t]{2}{*}{ EVI-15 } & kv325 & 97 & TS1 RF & 99.3 \\
\hline & & SJ3 RF & 99 & \\
\hline \multicolumn{5}{|c|}{ Anti-Hib (capsular polysaccharide [PS]) } \\
\hline SB5/D6 & $4 \mathrm{~A} V \lambda 7$ & 91 & none & - \\
\hline RAY4 & $4 \mathrm{~A} V \lambda 7$ & 91 & & \\
\hline LSF2 & $4 \mathrm{~A} V \lambda 7$ & 90 & & \\
\hline $16 \mathrm{M} 3 \mathrm{C} 8$ & $2.1 \mathrm{~V} \lambda 2$ & 89 & none & - \\
\hline JB21 & $2.1 \mathrm{~V} \lambda 2$ & 91 & & \\
\hline $\mathrm{RC} 3$ & $\mathrm{~A} 2 \mathrm{~V}_{\kappa} 2$ & 100 & none & - \\
\hline \multirow[t]{2}{*}{ ED6.1 } & $\mathrm{O} 12 \mathrm{~V}_{k} 1$ & 94 & $15 \mathrm{~A}$ anti-I & 99.7 \\
\hline & $\begin{array}{c}\text { Putative } \\
\text { germline gene }\end{array}$ & $\begin{array}{c}\text { Percent } \\
\text { similarity* }\end{array}$ & $\begin{array}{l}\text { Related anti- } \\
\text { pathogen } \mathrm{Ab}\end{array}$ & $\begin{array}{c}\text { Percent } \\
\text { similarity }\end{array}$ \\
\hline LS2 anti-Pr2 & $\mathrm{Vg} \mathrm{V}_{\kappa} 3$ & 97 & none & - \\
\hline Kim13.1 poly & $\mathrm{Vg} \mathrm{V}_{\kappa} 3$ & 99.3 & & \\
\hline 2A4 anti-DNA & HK102 VK1 & 85 & none & - \\
\hline TS3 RF & $\mathrm{A} 23 \mathrm{~V}_{k} 2$ & 100 & none & - \\
\hline Kim4.6 anti-DNA & $1 \mathrm{v} 117 \mathrm{~V} \lambda 1$ & 100 & none & - \\
\hline L1 RF & $1 \mathrm{v} 1 \mathrm{~L} 1 \mathrm{~V} \lambda 1$ & 99 & none & - \\
\hline
\end{tabular}

The data of $\mathrm{H} 2, \mathrm{H} 3$, and $\mathrm{V} 1$ are from the current communication; all the other data are from the literature: EVI-15 (21); anti-Hib antibodies (61); LS2 (50); Kim13.1 polyreactive autoantibody (51); 2A4 (54); TS1 and 3, and SJ3 (59); Kim4.6 and lv117 (57); L1 RF and lv1L1 (42);

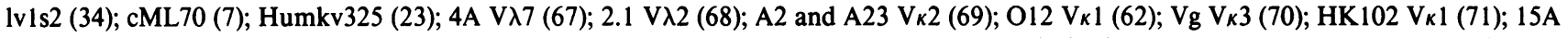
anti-I (63). * The percent similarity after each germline gene denotes its DNA sequence similarity to the $\mathrm{V}$ gene-encoded region in the preceding antibody. ${ }^{\ddagger}$ The percent similarity after each expressed $\mathrm{V}$ sequence denotes its DNA sequence similarity to the preceding germline $\mathrm{V}$ gene on the same section.

quences, and transcriptional and translational regulatory sequences. To examine these possibilities, the potentially functional antibody repertoires in normal individuals will have to be analyzed in detail. Further experiments are warranted to determine the precise relationship between anti-pathogen antibodies and autoantibodies, and eventually to define the expression and regulation of $\mathrm{Ig} \mathrm{V}$ genes.

\section{Acknowledgments}

The authors gratefully acknowledge the secretarial assistance of Ms. Jane Uhle in the preparation of the manuscript.

Funding for this research is supported in part by grants AI-32243, AR-25443, AR-40770, and RR-00833 from the National Institutes of Health.

\section{References}

1. Tonegawa, S. 1983. Somatic generation of antibody diversity. Nature (Lond.). 302:575-581.

2. Honjo, T., and S. Habu. 1985. Origin of immune diversity: genetic variation and selection. Annu. Rev. Biochem. 54:803-830.

3. Kodaira, M., T. Kinashi, I. Umemura, F. Matsuda, T. Noma, Y. Ono, and
T. Honjo. 1986. Organization and evolution of variable region genes of the human immunoglobulin heavy chain. J. Mol. Biol. 190:529-541.

4. Berman, J. E., S. J. Mellis, R. Pollock, C. L. Smith, H. Suh, B. Heinke, C. Kowal, U. Surti, L. Chess, C. R. Cantor, et al. 1988. Content and organization of the human Ig VH locus: definition of three new VH families and linkage to the Ig CH locus. EMBO (Eur. Mol. Biol. Organ.) J. 7:727-738.

5. Zachau, H. G. 1989. Immunoglobulin light-chain genes of the kappa type in man and mouse. In Immunoglobulin Genes. T. Honjo, F. W. Alt, and T. H. Rabbitts, editors. Academic Press Ltd., London. 91-109.

6. Meindl, A., H.-G. Klobeck, R. Ohnheiser, and H. G. Zachau. 1990. The Vk gene repertoire in the human-germline. Eur. J. Immunol. 20:1855-1863.

7. Combriato, G. and H.-G. Klobeck. 1991. Vl and Jl-Cl gene segments of the human immunoglobulin 1 light chain locus are separated by $14 \mathrm{~kb}$ and rearrange by a deletion mechanism. Eur. J. Immunol. 21:1513-1522.

8. Chen, P. P., N. J. Olsen, P.-M. Yang, R. W. Soto-Gil, T. Olee, K. A. Siminovitch, and D. A. Carson. 1990. From human autoantibodies to fetal antibody repertoire to B cell malignancy: It's a small world after all. Int. Rev. Immunol. 5:239-251.

9. Pascual, V., J. Andris, and J. D. Capra. 1990. Heavy chain variable region gene utilization in human antibodies. Int. Rev. Immunol. 5:231-238.

10. Dersimonian, H., A. Long, D. Rubinstein, B. D. Stollar, and R. S. Schwartz. 1990. Vh genes of human autoantibodies. Int. Rev. Immunol. 5:253264.

11. Pascual, V., and J. D. Capra. 1991. Human immunoglobulin heavy-chain variable region genes: organization, polymorphism, and expression. Adv. Immunol. 49:1-74.

12. Chen, P. P., and D. A. Carson. 1991. Molecular and genetic studies of human autoantibodies. In Molecular Autoimmunity: Molecular, Oncologic, Ge- 
netic Immunology and Clinical Aspects. N. Talal, editor. Academic Press Ltd., London. 65-79.

13. Chen, P. P., S. Fong, F. Goni, G. J. Silverman, R. I. Fox, M.-F. Liu, B. Frangione, and D. A. Carson. 1988. Cross-reacting idiotypes on cryoprecipitating rheumatoid factor. Springer Semin. Immunopathol. 10:35-55.

14. Dersimonian, H., R. S. Schwartz, K. J. Barrett, and B. D. Stollar. 1987. Relationship of human variable region heavy chain germ-line genes to genes encoding anti-DNA autoantibodies. J. Immunol. 139:2496-2501.

15. Chen, P. P. 1990. Structural analyses of human developmentally regulated Vh3 genes. Scand. J. Immunol. 32:257-267.

16. Sanz, I., P. Casali, J. W. Thomas, A. L. Notkins, and J. D. Capra. 1989. Nucleotide sequences of eight human natural autoantibody $\mathrm{V}-\mathrm{H}$ regions reveals apparent restricted use of V-H families. J. Immunol. 142:4054-4061.

17. Schroeder Jr., H. W., J. L. Hillson, and R. M. Perlmutter. 1987. Early restriction of the human antibody repertoire. Science (Wash. DC). 238:791-793.

18. Schroeder Jr., H. W., and J. Y. Wang. 1990. Preferential utilization of conserved immunoglobulin heavy chain variable gene segments during human fetal life. Proc. Natl. Acad. Sci. USA. 87:6146-6150.

19. Hillson, J. L., and R. M. Perlmutter. 1990. Autoantibodies and the fetal antibody repertoire. Int. Rev. Immunol. 5:215-230.

20. Coutinho, A. 1989. Beyond clonal selection and network. Immunol. Rev. 110:63-87.

21. Newkirk, M. M., H. Gram, G. F. Heinrich, L. Ostberg, J. D. Capra, and R. L. Wasserman. 1988. The complete protein sequences of the variable regions of the cloned heavy and light chains of a human anti-cytomegalovirus antibody reveal a striking similarity to human rheumatoid factors of the Wa idiotypic family. J. Clin. Invest. 81:1511-1518.

22. Carson, D. A., P. P. Chen, and T. J. Kipps. 1991. New roles for rheumatoid factor. J. Clin. Invest. 87:379-383.

23. Chen, P. P., K. Albrandt, T. J. Kipps, V. Radoux, F.-T. Liu, and D. A. Carson. 1987. Isolation and characterization of human VkIII germline genes: implications for the molecular basis of human VkIII light chain diversity. $J$. Immunol. 139:1727-1733.

24. Masuho, Y., T. Sugano, Y.-I. Matsumoto, S. Sawada, and K. Tomibe. 1986. Generation of hybridomas producing human monoclonal antibodies against herpes simplex virus after in vitro stimulation. Biochem. Biophys. Res. Commun. 135:495-500.

25. Fujinaga, S., T. Sugano, Y.-I. Matsumoto, Y. Masuho, and R. Mori. 1987 Antiviral activities of human monoclonal antibodies to herpes simplex virus. $J$. Infect. Dis. 155:45-53.

26. Sugano, T., Y. Matsumoto, C. Miyamoto, and Y. Masuho. 1987. Hybridomas producing human monoclonal antibodies against varicella-zoster virus Eur. J. Immunol. 17:359-364.

27. Saiki, R. K., D. H. Gelfand, S. Stoffel, S. J. Scharf, R. Higuchi, G. T. Horn, K. B. Mullis, and H. A. Erlich. 1988. Primer-directed enzymatic amplification of DNA with a thermostable DNA polymerase. Science (Wash. DC). 239:487-491.

28. Loh, E. Y., J. F. Elliott, S. Cwirla, L. L. Lanier, and M. M. Davis. 1989. Polymerase chain reaction with single-sided specificity: analysis of $\mathrm{T}$ cell receptor delta chain. Science (Wash. DC). 243:217-220.

29. Robbins, D. L., T. P. Kenny, M. J. Coloma, J. V. Gavilondo-Cowley, R. W. Soto-Gil, P. P. Chen, and J. W. Larrick. 1990. Serological and molecular characterization of a human monoclonal rheumatoid factor derived from rheumatoid synovial cells. Arthritis Rheum. 33:1188-1195.

30. Messing, J. 1983. New M13 vectors for cloning. Methods Enzymol 101:20-78.

31. Devereux, J., P. Haeberli, and O. Smithies. 1984. A comprehensive set of sequence analysis programs for the VAX. Nucleic Acids Res. 12:387-395.

32. Matthyssens, G., and T. H. Rabbitts. 1980 . Structure and multiplicity of genes for the human immunoglobulin heavy chain variable region. Proc. Natl. Acad. Sci. USA 77:6561-6565.

33. Chen, P. P., M. Liu, S. Sinha, and D. A. Carson. 1988. A 16/6 idiotype positive anti-DNA antibody is encoded by a conserved $\mathrm{Vh}$ gene with no somatic mutation. Arthritis Rheum. 31:1429-1431.

34. Bernard, F., P. Chuchana, J.-P. Frippiat, L. Buluwela, and M.-P. Lefranc 1990. Genomic sequence of IGLV1S2, a human immunoglobulin variable lambda gene belonging to subgroup I. Nucleic Acids Res. 18:555.

35. Shlomchik, M. J., A. Marshak-Rothstein, C. B. Wolfowicz, T. L. Rothstein, and M. G. Weigert. 1987. The role of clonal selection and somatic mutation in autoimmunity. Nature (Lond.). 328:805-811.

36. Ichihara, Y., H. Matsuoka, and Y. Kurosawa. 1988. Organization of human immunoglobulin heavy chain diversity gene loci. EMBO (Eur. Mol. Biol. Organ.) J. 7:4141-4150.

37. Ellison, J., and L. Hood. 1982. Linkage and sequence homology of two human immunoglobulin gamma heavy chain constant region genes. Proc. Natl. Acad. Sci. USA. 79:1984-1988.

38. Udey, J. A., and B. Blomberg. 1987. Human lambda light chain locus: organization and DNA sequences of three genomic $\mathrm{J}$ regions. Immunogenetics. 25:63-70.
39. Dariavach, P., G. Lefranc, and M.-P. Lefranc. 1987. Human immunoglobulin $\mathrm{C}_{\text {lambda }} 6$ gene encodes the $\mathrm{Kern}^{+} \mathrm{Oz}^{-}$lambda chain and $\mathrm{C}_{\text {lambda }} 4$ and $\mathrm{C}_{\text {lambda }} 5$ are pseudogenes. Proc. Natl. Acad. Sci. USA. 84:9074-9078.

40. Sanz, I., P. Kelly, C. Williams, S. Scholl, P. Tucker, and J. D. Capra. 1989. The smaller human $\mathrm{V}_{\mathrm{H}}$ gene families display remarkably little polymorphism. EMBO (Eur. Mol. Biol. Organ.) J. 8:3741-3748.

41. Lee, K. H., F. Matsuda, T. Kinashi, M. Kodaira, and T. Honjo. 1987. A novel family of variable region genes of the human immunoglobulin heavy chain. J. Mol. Biol. 195:761-768.

42. Olee, T., E. W. Lu, D.-F. Huang, R. W. Soto-Gil, M. Deftos, F. Kozin, D. A. Carson, and P. P. Chen. 1992. Genetic analysis of self-associating IgC rheumatoid factors from two rheumatoid synovia implicates an antigen driven response. J. Exp. Med. 175:831-842.

43. Friedman, D. F., E. A. Cho, J. Goldman, C. E. Carmack, E. C. Besa, R. R. Hardy, and L. E. Silberstein. 1991. The role of clonal selection in the pathogenesis of an autoreactive human B cell lymphoma. J. Exp. Med. 174:525-537.

44. Larrick, J. W., L. Danielsson, C. A. Brenner, M. Abrahamson, K. E. Fry, and C. A. K. Borrebaeck. 1989. Rapid cloning of rearranged immunoglobulin genes from human hybridoma cells using mixed primers and the polymerase chain reaction. Biochem. Biophys. Res. Commun. 160:1250-1256.

45. Andris, J. S., S. Johnson, S. Zolla-Pazner, and J. D. Capra. 1991. Molecular characterization of five human anti-human immunodeficiency virus type 1 antibody heavy chains reveals extensive somatic mutation typical of an antigendriven immune response. Proc. Natl. Acad. Sci. USA. 88:7783-7787.

46. Adderson, E. E., P. G. Shackelford, A. Quinn, and W. L. Carroll. 1991. Restricted Ig H chain $\mathrm{V}$ gene usage in the human antibody response to Haemophilus influenzae type b capsular polysaccharide. J. Immunol. 147:1667-1674.

47. Soto-Gil, R. W., T. Olee, B. K. Klink, T. P. Kenny, D. L. Robbins, D. A Carson, and P. P. Chen. 1992. A systematic approach to define the germline gene counterparts of a mutated autoantibody from a rheumatoid arthritis patient. Arthritis Rheum. 35:356-363.

48. Humphries, C. G., A. Shen, W. A. Kuziel, J. D. Capra, F. R. Blattner, and P. W. Tucker. 1988. A new human immunoglobulin VH family preferentially rearranged in immature B-cell tumors. Nature (Lond.). 331:446-449.

49. Harindranath, N., I. S. Goldfarb, H. Ikematsu, S. E. Burastero, R. L. Wilder, A. L. Notkins, and P. Casali. 1991. Complete sequence of the genes encoding the $V_{h}$ and $V_{1}$ regions of low- and high-affinity monoclonal IgM and IgA1 rheumatoid factors produced by $\mathrm{CDS}^{+} \mathrm{B}$ cells from a rheumatoid arthritis patient. Int. Immunol. 3:865-875.

50. Silberstein, L. E., S. Litwin, and C. E. Carmack. 1989. Relationship of variable region genes expressed by a human $B$ cell lymphoma secreting pathologic anti- $\mathrm{Pr}_{2}$ erythrocyte autoantibodies. J. Exp. Med. 169:1631-1643.

51. Siminovitch, K. A., V. Misener, P. C. Kwong, P.-M. Yang, C. A. Laskin, E. Cairns, D. Bell, L. A. Rubin, and P. P. Chen. 1990. A human anti-cardiolipin autoantibody is encoded by developmentally restricted heavy and light chain variable region genes. Autoimmunity. 8:97-105.

52. Pascual, V., I. Randen, K. Thompson, M. Sioud, O. Forre, J. Natvig, and J. D. Capra. 1990. The complete nucleotide sequences of the heavy chain variable regions of six monospecific rheumatoid factors derived from Epstein-Barr virustransformed B cells isolated from the synovial tissue of patients with rheumatoid arthritis. J. Clin. Invest. 86:1320-1328.

53. Hoch, S., and J. Schwaber. 1987. Identification and sequence of the V-H gene elements encoding a human anti-DNA antibody. J. Immunol. 139:16891693.

54. Davidson, A., A. Manheimer-Lory, C. Aranow, R. Peterson, N. Hannigan, and B. Diamond. 1990. Molecular characterization of a somatically mutated anti-DNA antibody bearing two systemic lupus erythematosus-related idiotypes. J. Clin. Invest. 85:1401-1409.

55. Hughes-Jones, N. C., J. M. Bye, D. Beale, and J. Coadwell. 1990. Nucleotide sequences and three-dimensional modelling of the $\mathrm{V}_{\mathrm{H}}$ and $\mathrm{V}_{\mathrm{L}}$ domains of two human monoclonal antibodies specific for the $\mathrm{D}$ antigen of the human $\mathrm{Rh}$-bloodgroup system. Biochem. J. 268:135-140.

56. Sanz, I., H. Dang, M. Takei, N. Talal, and J. D. Capra. 1989. V-H sequence of a human anti-Sm autoantibody. J. Immunol. 142:883-887.

57. Siminovitch, K. A., V. Misener, P. C. Kwong, Q.-L. Song, and P. P. Chen 1989. A natural autoantibody is encoded by germline heavy and lambda light chain variable region genes without somatic mutation. J. Clin. Invest. 84:16751678 .

58. Alexandre, D., P. Chuchana, F. Brockly, A. Blancher, G. Lefranc, and M.-P. Lefranc. 1989. First genomic sequence of a human Ig variable lambda gene belonging to subgroup I: functional genes, pseudogenes and vestigial sequences are interspersed in the IGLV locus. Nucleic Acids Res. 17:3975.

59. Victor, K. D., I. Randen, K. Thompson, O. Forre, J. B. Natvig, S. M. Fu, and J. C. Capra. 1991. Rheumatoid factors isolated from patients with autoimmune disorders are derived from germline genes distinct from those encoding the $\mathrm{Wa}, \mathrm{Po}$, and Bla cross-reactive idiotypes. J. Clin. Invest. 87:1603-1613.

60. Ezaki, I., H. Kanda, K. Sakai, N. Fukui, M. Shingu, M. Nobunaga, and T. Watanabe. 1991. Restricted diversity of the variable region nucleotide sequences 
of the heavy and light chains of a human rheumatoid factor. Arthritis Rheum. 34:343-350.

61. Adderson, E. E., P. G. Shackelford, R. A. Insel, A. Quinn, P. M. Wilson, and W. L. Carroll. 1992. Immunoglobulin light chain variable region gene sequences for human antibodies to Haemophilus influenzae type b capsular polysaccharide are dominated by a limited number of $\mathrm{Vk}$ and $\mathrm{Vl}$ segments and $\mathrm{VJ}$ combinations. J. Clin. Invest. 89:729-738.

62. Pargent, W., A. Meindl, R. Thiebe, S. Mitzel, and H. G. Zachau. 1991. The human immunoglobulin $\mathbf{k}$ locus: characterization of the duplication $\mathrm{O}$ regios. Eur. J. Immunol. 21:1821-1827.

63. Silberstein, L. E., L. C. Jefferies, J. Goldman, D. Friedman, J. S. Moore, P. C. Nowell, D. Roelcke, W. Pruzanski, J. Roudier, and G. J. Silverman. 1992. Variable region gene analysis of pathologic human autoantibodies to the related $\mathrm{i}$ and I red blood cell antigens. Blood. 78:2372-2386.

64. Braun, J., L. Berberian, L. King, I. Sanz, and H. L. Govan III. 1992. Restricted use of fetal VH3 immunoglobulin genes by unselected B cells in the adult. Predominance of 56p1-like VH genes in common variable immunodefciency. J. Clin. Invest. 89:1395-1402.

65. Blackman, M., J. Kappler, and P. Marrack. 1990. The role of the T cell repertoire in positive and negative selection of developing T cells. Science (Wash. DC). 248:1335-1341.
66. Rolink, A., and F. Melchers. 1991. Molecular and cellular origins of B lymphocyte diversity. Cell. 66:1081-1094.

67. Anderson, M. L. M., M. F. Szajnert, J. C. Kaplan, L. McColl, and B. D. Young. 1984. The isolation of a human Ig $\mathrm{V}_{\text {lambda }}$ gene from a recombinant library of chromosome 22 and estimation of its copy number. Nucleic Acids Res. 12:6647-6661.

68. Brodkly, F., D. Alexandre, P. Chuchana, S. Huck, G. Lefranc, and M.-P. Lefranc. 1989. First nucleotide sequence of a human immunoglobulin variable lambda gene belonging to subgroup II. Nucleic Acids Res. 17:3976.

69. Straubinger, B., E. Huber, W. Lorenz, E. Osterholzer, W. Pargent, M. Pech, H.-D. Pohlenz, F.-J. Zimmer, and H. G. Zachau. 1988. The human VK locus: characterization of a duplicated region encoding 28 different immunoglobulin genes. J. Mol. Biol. 199:23-34.

70. Pech, M., and H. G. Zachau. 1984. Immunoglobulin genes of different subgroups are interdigitated within the Vk locus. Nucleic Acids Res. 12:92299236.

71. Bentley, D. L., and T. H. Rabbitts. 1980. Human immunoglobulin variable region genes-DNA sequences of two $\mathrm{V}(\mathrm{k})$ genes and a pseudogene. Nature (Lond.). 288:730-733. 